\title{
Dlaczego widok cierpienia bohaterów dramatu sprawia nam przyjemność? Rozważania o inspiracji etyki i estetyki Fryderyka Schillera ze strony Jean-Baptistéa Du Bos
}

Głośna w XVIII wieku książka Jeana-Baptista Du Bos Réflexions critiques sur la poésie et sur la peinture wywołała ożywioną dyskusję na typowy dla estetyki i filozofii sztuki temat: celu jakiemu służą sztuki piękne1. Autor twierdził, że celem tym jest dostarczanie przyjemności. Podobne stanowisko reprezentuje większość francuskich estetyków oświecenia, np. Charles Batteux, który w swym słynnym dziele Les Beaux-Arts réduits à un même principe ${ }^{2}$, przeciwstawia przyjemność duchową jako wspólną dziedzinę wszystkich sztuk pięknych, pozostałym ludzkim umiejętnościom, których cel stanowi dostarczanie nam tego, co jest praktycznie przydatne do życia.

W granice tak na pozór oczywistego rozważania trudno jest jednak wtłoczyć sztuki dramatyczne. Jaką bowiem przyjemność możemy czerpać z widoku cudzego nieszczęścia i cierpienia? Postacie Medei mordującej własne dzieci z chęci dokonania zemsty na swym mężu; oszalałej z miłości do pasierba Fedry, Szekspirowskiego Ryszarda III ogarniętego chorobliwym pożądaniem władzy są moralnie odpychające i trudno byłoby tu mówić o rodzącej się w wyobraźni widzów przyjemności. A jednak z jakiegoś powodu są to

\footnotetext{
${ }^{1}$ J.-B. Du Bos, Réflexions critiques sur la poésie et sur la peinture, Paris 1993.

2 Por. Ch. Batteux, Les Beaux-Arts réduits à un même principe, Paris 1989, s. 81
} 
postacie niezwykłe i fascynujące, chciałoby się powiedzieć, że wręcz perwersyjnie przyciągające widzów do teatru. Nawet jeżeli postaci, tak jednoznacznie negatywnych moralnie nie pojawia się $\mathrm{w}$ treści dramatu zbyt wiele, to w wyniku ich działania pozytywni bohaterowie zwykle przechodzą katusze, cierpią i kończą nieszczęśliwie. Cóż zatem przyciąga nas do teatru, w którym wystawiane są tragedie? I na jakiej podstawie można twierdzić, że ten rodzaj sztuki nie tylko sprawia przyjemność, ale ma wręcz moc umoralniającą? Taki zaś pogląd był w XVIII wieku powszechny wśród estetyków i moralistów.

We wspomnianym powyżej dziele Réflexions critiques sur la poésie et sur la peinture $\mathrm{Du}$ Bos dochodzi do wniosku, że bezpośrednim powodem tego, iż mroczne i krwawe czyny bohaterów przyciągają nas do teatru jest nuda ${ }^{3}$. Człowiekowi spętanemu przez więzy cywilizacji coraz trudniej jest znaleźć zajęcie, które pochłaniałoby go bez reszty. Podstawowe potrzeby biologiczne związane z przetrwaniem nie wymagają już emocji całej jego siły, pozostaje nadwyżka, którą można spożytkować na potrzeby duchowe. Szuka on zatem nowego gatunku przyjemności, którym może się stać jakiekolwiek pobudzenie emocjonalne, choćby i nieprzyjemne. $\mathrm{Z}$ faktem tym francuski myśliciel wiąże fenomen naszego upodobania nie tylko do sztuk dramatycznych, ale także na przykład do walk gladiatorów, czy egzekucji skazańców.

Ta naturalna emocja, która wznieca się w nas mechanicznie, kiedy widzimy naszych bliźnich w niebezpieczeństwie albo w nieszczęściu, nie ma dla nas innego powabu niż ten, że jest namiętnością, która porusza duszą i daje jej zajęcie; emocja ta roztacza czar zdolny [skłonić nas] do tego, by poszukiwać ją, wśród idei smutnych i przeszkadzających, które jej towarzyszą bądź po niej następują. Poruszenie, które przez rozum nie całkiem może zostać opanowane, jest przyczyną tego, że wielu ludzi zaczyna gonić za przedmiotami najbardziej rozdzierającymi serce ${ }^{4}$.

Nie oznacza to jednak, że do teatru ciągnie nas tylko żądza taniej rozrywki i zabicia wolnego czasu. Gdy sztuki w ogóle powstawały, twórcy być może myśleli głównie o przyjemnościach zmysłów i wyobraźni, ale w miarę rozwoju działalności artystycznej oczywisty stawał się fakt, że budząc w ludzkich sercach namiętności można nauczać wrażliwości na cierpienie, a nawet uodparniać widza na własne nieszczęścia.

${ }^{3}$ Kwestia ta stanie się później tematem dyskusji pomiędzy Mosesem Mendelssohnem a Gottholdem Ephraimem Lessingiem. Por. A. Lombard, L'abbé du Bos un initiateur de la pensée moderne (1670-1742), Paris 1913, s. 364.

${ }^{4}$ J.-B. Du Bos, Réflexions critiques sur la poésie et sur la peinture, Paris 1993, s. 5. 
Przyjemność odczuwana z podejmowanego przez malarzy i poetów naśladownictwa przedmiotów wzbudzających w nas namiętności, które w rzeczywistości byłaby dla nas ciężarem, jest przyjemnością czystą. Nie pociąga ona za sobą takich niedogodności, jak poważne emocje spowodowane przez towarzyszący im [naturalny] przedmiot ${ }^{5}$.

Sztuki dramatyczne, ale też i plastyczne, przedstawiają często zdarzenia tak okrutne, że ich widok uobecniający się w naturze zadręczyłby naszą duszę. Rzeź niewiniątek z obrazu Le Bruna czy śmierć Fedry ze sztuki Racine’a, gdy je oglądać na żywo, byłby przeżyciem tak traumatycznym, że niektórzy odbiorcy być może nigdy nie mogliby się już cieszyć życiem. W sztuce zaś takie szokujące sceny wzbudzają w nas na ogół tylko silne wzruszenie. Namiętności wywoływane przez artystów nie trwają długo, zazwyczaj tylko, do końca spektaklu. Po wyjściu z teatru widz jest świadomy, że patrzył na dzieje postaci fikcyjnych, których cierpienia też były tylko wyimaginowane. Dystans pomiędzy światem a sceną powoduje, że oglądający dramat czuje się bezpieczny i największe tragedie tylko nas powierzchownie „muskają”.

Oto to samo upodobanie, które każe nam kochać niepokój i trwogę, które wywołują w nas niebezpieczeństwa, gdy odczuwamy je, jako nie będące naszym udziałem, wzrusza nas - mówi Lukrecjusz - kiedy widzimy z wybrzeża okręt walczący z falami, które chcą go pochłonąć, albo gdy patrzymy na bitwę z odległości, z której pozostajemy bezpieczni ${ }^{6}$.

Du Bos zdaje się nie zauważać problemu, że w przytoczonym przypadku mamy do czynienia z objawieniem się wzniosłości. Obserwowane przez widza zjawiska, oddziałując na instynkt samozachowawczy, wzbudzają przyjemne odczucie niepokoju, a nawet i grozy, oczywiście pod warunkiem, że nie zakłóci ich obawa o własne bezpieczeństwo. Psychologiczną wykładnię emocji, jakie towarzyszą zjawisku wzniosłości, formułuje dopiero Edmund Burke w swych Dociekaniach filozoficznych o pochodzeniu naszych idei wzniosłości i piękna ${ }^{7}$, a rozwinie je i da im filozoficzne podstawy Immanuel Kant w Krytyce władzy sqdzenia ${ }^{8}$.

\footnotetext{
${ }^{5}$ Tamże, s. 10.

${ }^{6}$ Tamże, s. 5.

${ }^{7}$ E. Burke, Dociekania filozoficzne o pochodzeniu naszych idei wzniosłości i piękna, przeł. P. Graff, Warszawa 1968, s. 63-99.

${ }^{8}$ I. Kant, Krytyka władzy sądzenia, przeł. J. Gałecki, Warszawa 1986, s. 130-166.
} 
Przeświadczenie, że teatr działa w społeczeństwie jako instytucja mająca na celu wzbudzenie powszechnego katharsis oczyszczającego i wzmacniającego ludzkiego ducha, na gruncie kultury niemieckiej przejmie od Du Bos Gotthold Ephraim Lessing, a za nim Fryderyk Schiller. Co prawda w Dramaturgii hamburskiej Lessing tylko raz wspomina nazwisko swojego francuskiego poprzednika, u Schillera próżno zaś szukać w ogóle jakiejkolwiek wzmianki na jego temat, ale analizując genealogię pojęć nie mamy wątpliwości, że taki wpływ faktycznie istniał, i że był bardzo istotny ${ }^{9}$. Dla żadnego z wymienionych estetyków moralne oddziaływanie sztuki na widza nie polega na bezpośrednim, obrazowym przedstawieniu, jak należy postępować. Lecz raczej na uodpornieniu widza na przeciwności losu. Najbardziej bezpośrednio związek pomiędzy oddziaływaniem dramatu a etyką odwzorowany jest u Du Bos, który twierdził, że oczyszczające działanie sztuki (każdej, nie tylko tragedii) polega na uzmysłowieniu widzowi konsekwencji, do jakich może prowadzić nieopanowanie namiętności. Kiedy sobie uzmysłowimy, a potem uświadomimy, dokąd wiedzie, nawet w przypadku ludzi najmądrzejszych i najodważniejszych, nienawiść, zazdrość, ambicja, pycha, czy też niczym nieposkromiona wściekłość, być może postaramy się zrobić wszystko, by ujarzmić w sobie najmniejsze nawet symptomy tych emocji. Dla Lessinga wspomniany związek sztuki i moralności jest już dużo luźniejszy. Sztuka sceniczna ma być w jego koncepcji wyrazicielem nie konkretnych zasad moralnych, ale koncentracji na kolejach życia poszczególnych postaci dramatu tak, byśmy jak najmocniej odczuli, że ich los może stać się i naszym losem. Rozdźwięk pomiędzy sferą etyki i estetyki jeszcze silniej uwidacznia się w tekstach Fryderyka Schillera, z całą pewnością za sprawą lektury pism Immanuela Kanta.

Dla Schillera teatr stanowi żywe zwierciadło, w którym, w sposób czysty, odbijają się nasze postępki i losy. Podczas, gdy w codziennym życiu wszelkie postępowanie, wyrazistość charakterów, jednoznaczność czynów cnotliwych i podłych mieszają się z sobą i gubią w zawiłych ciągach przeróżnych zdarzeń, na scenie pojawiają się oczyszczone z cech przypadkowych i wyraźnie określone, w taki sposób, by nawet najmniej spostrzegawczy widz był w stanie uświadomić sobie, jakie są losy istot występnych czy też heroicznych ${ }^{10}$. Zda-

9 Por. A. Lombard, L’abbé du Bos un initiateur de la pensée moderne (1670-1742), Paris 1913, s. 350-377.

${ }^{10}$ Por. F. Schiller, O współczesnym teatrze niemieckim, [w:] Goethe i Schiller o dramacie i teatrze. Wybór pism, przeł. O. Dobijanka, Wrocław 1959, s. 228 oraz F. Schiller, Teatr jako instytucja moralna, [w:] Goethe i Schiller o dramacie i teatrze, s. 237. 
niem Schillera, widok oglądanych tragedii z jednej strony buduje wrażliwość na ludzką krzywdę i zdolność empatii, z drugiej zaś hartuje naszego ducha tak, aby mógł on znieść nawet najbardziej okrutne zrządzenia losu ${ }^{11}$.

W trakcie pisania esejów O współczesnym teatrze niemieckim oraz Teatr jako instytucja moralna Schiller pozostaje jeszcze pod silnym wpływem Lessinga, a za jego pośrednictwem także i Du Bos. Ale już siedem lat później, pod oddziaływaniem dogłębnej lektury pism Kanta, jego poglądy ulegają znaczącej modyfikacji. Autor Zbójców nadal łączy problematykę etyczną i estetyczną, zgodnie z poglądami Shaftesbury’ego, który był mistrzem jego młodzieńczych lat, ale już nie w tak prosty i jednoznaczny sposób. Sztuka, głosi teraz Schiller, nie może być młodszą siostrą nauk moralnych, służącą do emocjonalnego zobrazowania ludzkich powinności. Cele obu dziedzin filozofii są teraz odmienne: moralność uczy, jak powinniśmy postępować bez względu na możliwość uzyskania szczęścia lub przyjemności wypływających z naszych uczynków. Co jednak ważniejsze (zwłaszcza z punktu widzenia estetyki), dziedziny te odwołują się do odmiennych władz poznawczych: etyka do rozumu, piękno do wyobraźni, pomieszanie tych dwóch dziedzin może im więc przynieść więcej szkód niż korzyści. Etyce dlatego, że zamiast opierać swe prawa na imperatywach rozumu zajmuje się kwestiami w jej wypadku pobocznymi, na przykład odczuciem piękna. A cóż, z czysto etycznego punktu widzenia, warta jest pomoc okazywana tylko tym, którzy wzbudzają nasze sympatie estetyczne? Działania charytatywne dotyczyłyby wówczas chyba tylko młodych i urodziwych, a omijały starych, chorych i ułomnych. Może więc powinniśmy kierować się emocjami, które, choć nie mają z rozumem wiele wspólnego, wzbudzą naszą aprobatę, jak litość, współczucie, zdolność empatii, poczucie wstydu, uprzejmość względem innych? To już lepsza propozycja. Kant nazywał je nawet cnotą, choć tylko adoptowaną, nie zaś autentyczną ${ }^{12}$. Jak zobaczymy, Schiller przejawia tu nawet nieco bardziej liberalne stanowisko niż królewiecki filozof i dopuszcza w dziedzinie etyki tzw. piękne emocje, których, jego zdaniem, nie należy się wstydzić.

Niestety etyka często może też zaszkodzić estetyce. Autor, który w nadmiernym stopniu forsował będzie pouczenia i porady umoralniające, stworzy dzieło, które utraci całą lekkość i zdolność dawania przyjemności, będące

\footnotetext{
${ }^{11}$ Por. F. Schiller, O wspótczesnym teatrze niemieckim, s. 235 oraz F. Schiller, Teatr jako instytucja moralna, s. 241/242.

${ }^{12}$ Por. I. Kant, Rozważania o uczuciu piękna i wzniosłości, przeł. D. Pakalski i M. Żelazny [w] tenże, Dzieła zebrane, t. 1, red. M. Jankowski, T. Kupś, Toruń 2010, s. 660/661.
} 
naturalnym atutem sztuk pięknych. Zdaniem Schillera nawet w ramach tak zwanej sztuki zaangażowanej w rozwój osobowości człowieka, jego poczucia niezależności, jak i zdolności do troski o innych, te ważne cele powinny pojawiać się niejako mimochodem. Nie nuży ona wówczas odbiorców, nie przytłacza i wbrew pozorom, dysponuje większą siłą oddziaływania.

jeśli jednak chodzi o doskonałość sztuki, nie jest bynajmniej obojętne, co jest jej celem, a co środkiem do celu. Jeśli sam cel jest moralny, to sztuka traci swą odrębność, która stanowi o jej sile, oraz urok przyjemności, dzięki któremu jej oddziaływanie jest tak skuteczne. Zabawa staje się poważnym zajęciem; a przecież właśnie przez zabawę może sztuka najlepiej spełniać swe zadanie ${ }^{13}$.

Gdy idzie o propagowanie wartości etycznych, wystarcza więc, że sztuka wzbudza w nas pozytywne emocje, jak wspomniane wcześniej współczucie dla cierpiących, świadomość wzniosłości ludzkiego ducha, a nawet zrozumienie i litość dla zbrodniarza. Widok piękna i wzniosłości budzi w nas nie tylko wzruszenie, ale i zrozumienie wartości, jaką jest nasza własna wolność, autonomia innych istnień, dzięki którym możemy wyrwać się ze świata zmysłów, wreszcie godność towarzysząca poczuciu powołania ku wyższym, duchowym celom ${ }^{14}$. Sama przyjemność, jaką odczuwamy czytając dramat lub oglądając jego sceniczną interpretację, powoduje więc, że jako wzniosła odczuwana jest też nasza moralność. W szystkich tych celów nie da się osiągnąć poprzez suche pouczenia czy też łajania kaznodziejów. Jednak występująca $\mathrm{w}$ tej roli przyjemność musi być bezinteresowna.

Takie przeświadczenie wynosi Schiller zarówno z lektury pism Shaftesbury'ego ${ }^{15}$, jak i Kanta ${ }^{16}$. Zadowolenie, jakie czerpiemy ze sztuki nigdy nie jest czysto zmysłowe. W obrazie cieszą nas nie ładne kolory, ale kompozycja całości, zatem nie czysto techniczna umiejętność malarza, ale jego zdolność do znalezienia ciekawych motywów, wybrania interesującego tematu, zbudowania całej kompozycji. W muzyce rolę tę pełni nie melodyjność poszczególnych instrumentów, ale umiejętność zestrojenia różnych dźwięków,

${ }^{13} \mathrm{~F}$. Schiller, O powodach, dla których tematy tragiczne dostarczaja nam przyjemności, [w:] Goethe i Schiller o dramacie i teatrze, s. 249.

${ }^{14}$ Por. F. Schiller, O wzniosłości, przeł. J. Prokopiuk [w:] tenże, Listy o estetycznym wychowaniu człowieka i inne rozprawy, Warszawa 1972, s. 182-183.

${ }^{15}$ Por. A.A.C. Shaftesbury, Moraliści, przeł. A. Grzeliński, [w:] tenże, List o entuzjazmie. Moraliści, Toruń 2007, s. 179 i nn.

${ }^{16}$ Por. I. Kant, Krytyka władzy sądzenia, przeł. J. Gałecki, Warszawa 1986, s. 95-99. 
czyli znów zdolność konstruowania harmonijnej całości ${ }^{17}$. W dramacie nie będą to zabawne dialogi, czy energetyzujące postacie, ale fabuła. To prawda, że również elementy zmysłowe współtworzą sztukę, oraz że z nich także czerpiemy przyjemności, ale są one wtedy przyjemnościami niższego rzędu. Nadając im zbyt wielką rangę, ocenialibyśmy dzieło, jak jelonek Shaftesbury'ego, który podziwia soczystą zieloną łąkę, ku której pociąga go smakowitość trawy, głód i pragnienie. Z perspektywy postawy bezinteresownej nie sposób pożądać piękna, jest ono bowiem tylko ideą, a nie przedmiotem empirycznym. Podziwiając obraz, możemy pożądać go jako rzeczy materialnej, ze względu na wartość rynkową, sentymentalną czy ambicjonalną, ale wówczas nie musi być piękny, bo cała satysfakcja płynie $z$ innych sfer naszego ducha niż te, które dotyczą wartości estetycznych.

Jak jednak pragnąć idei? Wydaje się przecież, że rozumiemy dzieło i czujemy zadowolenie $\mathrm{z}$ jego kontemplacji, albo go nie rozumiemy i wówczas na przykład przenosimy nasze zainteresowanie na inną dziedzinę sztuki lub próbujemy przeniknąć co też artysta miał na myśli. Lecz kontemplacja dzieła sztuki wymaga od nas nie tylko walorów przejawianych przez nasze władze percepcyjne, ale przede wszystkim zdolności duchowych.

Bezinteresowną nazywamy zaś taką przyjemność, która wymaga udziału sił duchowych, rozumu i wyobraźni, i którą wywołuje wyobrażenie; jest ona przeciwieństwem przyjemności fizycznej albo zmysłowej, która [...] jest bezpośrednim następstwem podniety fizycznej ${ }^{18}$.

Doznanie estetyczne nie jest więc biernym odczuciem przyjemności, podnieceniem czysto sensorycznym, ale wymaga także aktywności, umiejętności łączenia z sobą wyobrażeń, w taki sposób, by doznania zmysłowe układały się w harmonijną i celową całość ${ }^{19}$. Ten wymóg aktywnego, twórczego działania rozumu łączy idee dobra i piękna, choć kontemplacja tego ostatniego potrzebuje także wyobraźni. Powinowactwo etyki i estetyki szczególnie silnie uwydatnia się właśnie w tragedii, będącej dla Schillera sztuką, która umie

\footnotetext{
${ }^{17}$ Por. F. Schiller, O powodach, dla których tematy tragiczne dostarczają nam przyjemności, [w:] Goethe i Schiller o dramacie i teatrze, s. 250, oraz F. Schiller, Szkice z filozofii i estetyki, przeł. K. Kaśkiewicz, [w:] tenże, Kallias, czyli o pięknie, Kęty 2007, s. 89-90, a także: I. Kant, jw. ${ }^{18}$ F. Schiller, O powodach, dla których tematy tragiczne dostarczaja nam przyjemności, [w:] Goethe i Schiller o dramacie i teatrze, s. 249/250.

${ }^{19}$ Kant odróżnia tu zdolność produkcyjną (powstanie wyobrażenia pod wpływem nacisku zjawisk) oraz reprodukcyjną (zdolność reprodukcji przedstawień zmysłu wewnętrznego).
} 
wzruszać przez celowe budowanie odczucia wzniosłości, czyli przez patos. Odczucie wzniosłości rozumie niemiecki dramaturg w sposób dosłownie zgodny $\mathrm{z}$ naukami Kanta ${ }^{20} \mathrm{i}$ odnajduje $\mathrm{w}$ nim możliwość przejścia $\mathrm{z}$ estetyki do świata moralności, choć w nieco bardziej pragmatycznym wydaniu aniżeli to, które znajdujemy w Krytyce władzy sądzenia. Uczucie uwznioślające świadomość naszego godnego, ludzkiego powołania rodzi się ze zderzenia dwóch konstytuujących naszą umysłowość światów: zmysłowo-zwierzęcego i duchowego. Pierwszy z nich schodzi na drugi plan albo dlatego, że nie może ogarnąć idei nieskończoności (jak przy wzniosłości matematycznej), albo kiedy nie ma dość siły, by przeciwstawić się potędze natury (wówczas mamy do czynienia z wzniosłością dynamiczną). Widok czegoś ogromnego, jak na przykład piramid, czy strzelistej katedry gotyckiej sprawia, że czujemy się fizycznie mali, bo ani nasze zmysły, ani nasza zdolność wyobrażania nie ogarniają wielkości zjawiska, z którymi się stykamy. Ale zachodzi to tylko podczas obserwacji ze strony określonego miejsca. Nie możemy ani stać za daleko budowli, bo wówczas jej wielkości nie potrafimy odnieść do odczuwanej bezpośrednio wielkości własnego ciała, ani za blisko, gdyż wówczas tracimy umiejętność scalenia obserwowanej rzeczy. Dopiero uchwycenie całości ogromnej bryły i odniesienie do własnej fizyczno-zmysłowej małości, dającej się jednak z ową pierwszą wielkością porównać, uświadamia nam istnienie w nas idei rozumu. Uczucie, jakie takiej obserwacji towarzyszy, sprawia nam osobliwą przyjemność, określa bowiem nasz związek z niewymiernie nas przerastającym, ale przecież dającym się ogarnąć ogromem. Jeszcze silniej duchowy fenomen wynoszenia nas na wyższy (na razie tylko w kategoriach ilościowych) poziom wskazuje wzniosłość dynamiczna. Widok rozszalałego morza, wprawia nas w niepokój. Świadomość natury, jako potęgi zdolnej zmiażdżyć każdą naszą fizyczną zdolność obrony, wywołuje niepokój o własne życie. Ale jednocześnie czujemy przyjemny przypływ sił, bo odkrywamy, że wszystko, co do tej pory ceniliśmy: nasze życie, życie bliskich, dobrobyt i szczęście nie jest aż tak ważne, jak się nam dotąd wydawało. Przyjmowana przez nas dotąd w codziennych sytuacjach troska była tylko instynktowną zapobiegliwością zwierzęcia, którego życie podlega niszczącej sile natury. Świat wartości, zdolność do tworzenia idei, moralnego postępowania nie podlega jednak władzy natury, jaką potęgą by ona nie była. Dopiero od momentu uświadomienia sobie tego faktu czujemy, że wykraczamy poza świat zwierzęcy, a co się z tym wiąże, że zostaliśmy stworzeni do wyższych, aniżeli tylko biologiczne, celów.

\footnotetext{
${ }^{20}$ Por. przypis 8.
} 
Co ciekawe, odpowiedź, do jakich to wzniosłych celów jesteśmy stworzeni, z punktu widzenia estetyki jest zupełnie zbędna. Tu drogi estetyki i etyki się rozchodzą. Dla artysty, a zwłaszcza dla dramatopisarza, istotna jest jedynie wiedza, jak to niezwykle silne uczucie wzbudzić w odbiorcy. Etyk zaś chciałby wiedzieć, w jaki sposób możemy tę nowo odkrytą duchową wolność spożytkować.

Nieszczęsny los tragicznych bohaterów oraz klęska, której doznali w świecie zmysłowym uświadamia nam równocześnie wielkość ich ducha. Podziw dla Shakespeare'rowskiego Hamleta najsilniej odczuwamy w chwili śmierci bohatera, kiedy Horacy wypowiada słowa:

„Pękło szlachetne serce. Drogi książę;

Dobranoc. Zaśnij przy śpiewie aniołów"21.

Hamlet przegrywa, jego siła życia, jego szlachetność i rozumność. Przegrywa z potęgą zbrodniczego umysłu i z żądzą władzy człowieka, który nie cofa się przed zamordowaniem najbliższej rodziny. „Zacne serce” nie miało w tej walce żadnych szans, bohater został skazany przez los na śmierć już w chwili podjęcia próby ujawnienia morderstwa. Ale jednocześnie czujemy, że w globalnej perspektywie zwyciężył, bo nie zatracił swej wspaniałej, wielkiej (właściwie wzniosłej) natury. Jaspers powiedziałby, że w sytuacji granicznej, w jakiej się znalazł, rozjaśnia się jego egzystencja, poprzez spełnienie najskrytszych marzeń odbiorcy ${ }^{22}$. Cierpienie, jakie odczuwamy $\mathrm{w}$ teatrze, odnosi się tylko do sfery zmysłowej. W przeciwieństwie do tego duch tym silniej odczuwa zwycięstwo, im wyraźniej przegrywa natura zwierzęca, z jej pragnieniem życia i doczesnego szczęścia. „Przedmiot wzniosły jest więc z punktu widzenia rozumu celowy właśnie dlatego, że sprawia przykrość zmysłom i przynosząc cierpienie spowodowane strukturą władz zmysłowych cieszy objawieniem władz duchowych"23.

Często dokonany przez dramatopisarza wybór na głównego bohatera tragedii postaci szlachetnej podyktowany jest czysto pragmatyczną koniecznością zastosowania takich środków estetycznych, które są w stanie wzbudzić $\mathrm{w}$ widzach najsilniejsze wzruszenie. A cierpienie człowieka zacnego jest na ogół bardziej rozczulające aniżeli cierpienie łotra. W tym drugim wypadku zawsze mamy poczucie naturalnej sprawiedliwości, jaka dosięgła niegodziw-

\footnotetext{
${ }^{21}$ W. Shakespeare, Hamlet, książę Danii, przeł. S. Barańczak, Poznań 1990, s. 204 (akt V, sc. 2).

${ }^{22}$ Por. K. Jaspers, O tragiczności, przeł. A. Wołkowicz, [w:] Filozofia egzystencji, Warszawa 1990.

${ }^{23}$ F. Schiller, O powodach, dla których tematy tragiczne dostarczają nam przyjemności, [w:] Goethe i Schiller o dramacie i teatrze, s. 252.
} 
ca. Ostatecznym celem wzniosłości, pojawiającej się na scenie w formie patetyzmu, jest wzbudzenie $\mathrm{w}$ widzu przeświadczenia, że istnieje $\mathrm{w}$ nas szlachetne powołanie, którego celem nie jest bynajmniej osiągnięcie ziemskiego szczęścia. Ale dążeniu do owego celu bezwzględnie powinna towarzyszyć cnota, którą trudno przypisać na przykład innemu bohaterowi Shakespeare'a Ryszardowi III. Jego chorobliwe pragnienie władzy, nienasycona ambicja i żądza zwycięstwa, by przypomnieć przykład Kanta, ma w sobie coś z szalejącej burzy albo eksplodującego wulkanu, lawy pragnień, popędów i namiętności. Przywodzi na myśl potęgę przyrody, która niszczy wszystko, co mogłoby się kojarzyć ze spokojem, szczęściem, a nawet z możliwością przetrwania. Podobnie też jak w przypadku sił natury, niejako w myśl zasady: „każdemu działaniu towarzyszy przeciwdziałanie" furia Ryszarda III nie tylko spada na osoby, które staną tyranowi na drodze, ale przede wszystkim jest siłą niszczycielską jego samego. Widzimy człowieka, który sam siebie może doprowadzić do zguby, mordując w sobie wszystko, co dobre, szlachetne, a z czasem i wielkie. Odczuwamy wszak jego siłę, skądinąd zdolną nie tylko do wielkich, ale i dobrych czynów. Ale owo dobro bohater sam w sobie niszczy. Im głębiej zaś popada w szaleństwo, tym bardziej cierpimy wraz z nim. I wówczas, wbrew temu, co głosił Lessing w Dramaturgii hamburskiej jesteśmy jednak w stanie współczuć okrutnemu królowi ${ }^{24}$, bo jasno widzimy, że przeznaczenie powołało go nie tylko do czynów wielkich, ale i szlachetnych, tylko że on sam tę swoją przyrodzoną szansę zaprzepaszcza.

Najlepiej poznaje się moralną celowość, kiedy odnosi ona zwycięstwo w kontrowersji z innym układem celowości; tylko wtedy objawia się cała potęga prawa moralnego, kiedy ukazuje się je w walce $\mathrm{z}$ wszystkimi pozostałymi siłami natury i kiedy wszystkie one tracą w starciu z nim władzę nad ludzkim sercem. Przez owe siły natury rozumie się wszystko, co nie jest moralne, wszystko, co nie podlega najwyższej jurysdykcji rozumu, a więc uczucia, popędy, afekty, namiętności, jak również przymus fizyczny i los. Im straszniejsi przeciwnicy, tym chwalebniejsze zwycięstwo; tylko opór może wydobyć na jaw siłę

Zdaniem Schillera, podstawowym wyznacznikiem człowieczeństwa jest nie rozumność, ale wolność. Najgorszą rzeczą, jaką możemy uczynić bliźnie-

\footnotetext{
${ }^{24}$ Por. G. E. Lessing, Dramaturgia hamburska, przeł. Cz. Przymusiński, [w:] tenże, Dzieła wybrane, Warszawa 1959, red. A. Sowiński, t. 3, s. 328-333 (odcinek 79, z 2 lutego 1768).

${ }^{25}$ F. Schiller, O powodach, dla których tematy tragiczne dostarczaja nam przyjemności, [w:] Goethe i Schiller o dramacie i teatrze, s. 253/254.
} 
mu, jest zadanie mu gwałtu, będące zaprzeczeniem jego człowieczeństwa ${ }^{26}$. Mocą rozumu uświadamiamy sobie, że siła emanująca z Ryszarda III może być tylko niszczycielska, bo chorobliwe spojrzenie bohatera na świat wyklucza wszelkie działanie celowe. Jednak serce i wyobraźnia podpowiadają nam co innego. Potrafią ułożyć poszczególne czyny ogarniętego furią króla w zamierzoną i świadomą sekwencję, choćby tak odczytywana celowość miała na wskroś patologiczną genezę. Zdolność do celowego działania oparta na rozumnej naturze człowieka jest dla nas swoistą tarczą ochronną, „palladium naszej wolności”27. Nieszczęsny król otrzymał zatem od losu wszystko, co jest niezbędne do zachowania własnego człowieczeństwa, tyle że tych oferowanych mu środków użył w sposób niewłaściwy.

Oczywiście sposób rozumowania Schillera nie jest w tym wypadku na tyle rewolucyjny, by można było uznać, że postacie psychopaty, tyrana i mordercy są wyjątkowo dobrym materiałem przy konstruowaniu intrygi teatralnej. Dramaturg podkreśla, że dużo łatwiej daje się uzyskać wzruszenie, obserwując tragedię pozytywnej siły moralnej. Ale zdaje sobie sprawę, że schemat wywoływania uczucia wzniosłości jest czysto estetyczny i działa na wyobraźnię niezależnie od imperatywów rozumu. Uczucie wzniosłości łatwiej natomiast wzbudzi wyobrażenie celowości moralnej niż naturalnej, objawiającej się choćby w umiejętności snucia zawiłych intryg, dokonywania genialnych zbrodni, czy chociażby przejawach instynktu samozachowawczego. Choć nasza wyobraźnia i w takich wydarzeniach doszukuje się celowości, to niestety przyjemność odczuwania jej przez teatralnego widza będzie niższa. A o przyjemność przecież w sztuce chodzi; „...cóż nas jednak obchodzi natura $\mathrm{z}$ wszystkimi swymi celami i prawami, skoro przez swą niecelowość przyczynia się do ukazania nam w pełni blasku tkwiącej w nas celowości moralnej?" 28

Celowość naturalna uwidaczniająca się w postaciach intrygantów i zbrodniarzy potrzebna jest twórcy tylko po to, by główny bohater miał z kim walczyć. Bez oporu i bez walki nie zobaczymy ani siły duchowej, ani zdolności do samostanowienia, która jest podstawą zaistnienia moralności. Jak Schillera nauczył Kant, absolutna szczęśliwość, będąca nagrodą za czyny moralne, jest tylko ideą regulatywną rozumu i nie ma swojego przedstawienia empiryczne-

\footnotetext{
${ }^{26}$ Por. tenże, O wzniosłości, [w:] tenże, Listy o estetycznym wychowani człowieka i inne rozpra$w y$, s. 173.

${ }^{27}$ F. Schiller, O powodach, dla których tematy tragiczne dostarczają nam przyjemności, [w:] Goethe i Schiller o dramacie i teatrze, s. 253.

${ }^{28}$ F. Schiller, O powodach, dla których tematy tragiczne dostarczają nam przyjemności, s. 255.
} 
go. Artysta dramatyczny, którego rola polega na tym, by w formie zmysłowej pokazać to, co duchowe i niewidoczne, chcąc nam tę ideę pośrednio unaocznić, posługuje się zjawiskiem wzniosłości opartym na dwojakim uczuciu: przykrości w obliczu oddziaływania zmysłowej natury oraz rozkoszy wobec zwycięstwa ducha. Im silniejsza jest strona zmysłowa, tym mocniejsza w chwili zwycięstwa okaże się potęga ducha ${ }^{29}$. Nie ma nic mniej teatralnego niż postawa stoicka, twierdził Lessing ${ }^{30}$. Schiller zaś podkreślał, że: „... tylko opór może wydobyć na jaw siłę. Wynika z tego, że „najwyższa świadomość naszej moralnej natury może być utrzymana tylko w stanie gwałtownym, w walce, i że najwyższej radości moralnej zawsze będzie towarzyszył ból”31".

Podobny schemat dotyczyć może walki żywiołów rozgrywających się wewnątrz jednej postaci. Odczucie wzniosłości wobec potęgi ludzkiego ducha bywa wówczas nawet silniejsze. Dzieje się tak, ponieważ bohater, który w ostatecznym rozrachunku może okazać się pozytywny lub negatywny, chcąc ochronić swe zasady moralne przed potęgą własnych pragnień i popędów, musi te ostatnie w sobie zwalczyć, nawet jeśli wynikają one z pozornie szlachetnych pobudek (będzie to na przykład wybór pomiędzy miłością a powinnością, między pragnieniem a obowiązkiem itp.). W takim wypadku, obierając sobie za główną postać bohatera negatywnego, artysta ma nawet większe szanse wzbudzenia w widzu odczucia wzniosłości. Gdy widzimy zbrodniarza, cierpiącego z powodu żalu i wstydu za grzechy, których się dopuścił, wiemy, że drzemie w nim jeszcze okruch dobra. Gdy zaś dobry uczynek spowodowany skruchą za grzechy ściągnie na niego nieszczęście, wzruszenie będzie tym większe.

Wydawać by się mogło, że etyka i estetyka, przynajmniej w dużym stopniu, idą z sobą w parze, choć muszą działać w dwóch odrębnych sferach. Czyny moralne wymagają motywacji intelektu i obligatoryjnych nakazów, piękno zaś i wzniosłość odwołują się do wyobraźni i idei wolności. Nawet jeśli zdarzy się, że jakiś czyn wyda się wartościowy z perspektywy obu tych dziedzin ludzkiego ducha (np. będzie równocześnie dobry i wielki), to w istocie będzie

\footnotetext{
${ }^{29}$ Bardzo ciekawą interpretację tego samego zjawiska w rzeźbie możemy znaleźć w koncepcji George’a Simmela. Por. G. Simmel, Estetyka ciężkości, [w:] tenże, Most i drzwi. Wybór esejów, przeł. M. Łukasiewicz, Warszawa 2006, s. 86-93.

${ }^{30}$ G. E. Lessing, Laokoon, przeł. H. Zymon-Dębicki, [w:] Dzieła wybrane, red. A. Sowiński, t. 3, Warszawa 1959, rozdz. I, s. 15.

${ }^{31}$ F. Schiller, O powodach, dla których tematy tragiczne dostarczają nam przyjemności, s. 254 (cudzysłów wewnętrzny nadany zdaniu przez samego Schillera nie oznacza cytatu, ale wstawiony został po to, by podkreślić wagę wypowiedzi).
} 
to aprobata odmiennego rodzaju. Poświęcenie Leonidasa pod Termopilami, głosi Schiller, z punktu widzenia moralności, jest czynem podporządkowanym nadrzędnemu prawu moralnemu, a $\mathrm{z}$ punktu widzenia estetyki stanowi wyraz niezależności i hartu ducha, które potrafiły zrzucić z siebie jarzmo biologicznego instynktu przetrwania. Z punktu widzenia estetyki sam widok wydarzenia, któremu możemy przypisać ideę celowości sprawia wyobraźni przyjemność. Nie musi być to przyjemność rozumna, nie musi też chodzić o ostateczny efekt owej celowości. Zadowolenie płynące z kontemplacji zawiłej intrygi snutej przez Jagona z szekspirowskiego Otella jest równie silne, jak przemyślane działanie Edypa lub Antygony. Wyobraźnia nie troszczy się bowiem w takich wypadkach o ostateczny efekt. Wystarczy jej, że będzie mogła podążać w sposób samorzutny za ciągiem przyczynowym od jednego przypadku do drugiego. Im bardziej zawiłe i trudne do rozszyfrowania są poszczególne nici przedstawianych zdarzeń, tym większej przyjemności doznaje obserwator. Wyobraźnia lubi bawić się w wynajdywanie coraz to nowych układów celowości, choćby i pozornej. Schiller przyjmuje tu bardzo praktyczną zasadę wynikającą z Kantowskiego trzeciego znamienia sądu smaku: piękno jest celowością bez celu - celowością formalną, a nie obiektywną ${ }^{32}$. Jeśli gdziekolwiek w świecie odnajdujemy zasadę celowości mamy do czynienia z doskonałością, a nie pięknem. Na podobnej zasadzie sprawiają nam radość twory przyrody dzikiej, nawet nieożywionej. Piękna doszukujemy się wówczas w misternie utkanej sieci pajęczej, artyzmu zaś w dziele pszczoły lepiącej plastry miodu. Nie przeszkadza nam wówczas nawet uzmysłowienie sobie braku w przypadku tej „sztuki zwierzą?” świadomej genezy aktu twórczego. Podobnych problemów nie mamy też, dopatrując się (oczywiście w alegorycznej formie) rozmyślnie zastosowanej celowości w konstrukcji płatków śniegu, łuku tęczy, wschodach i zachodach słońca. Podobnie w teatrze nie razi nas fakt, że celowość, którą dostrzegamy w akcji dramatu prowadzi tylko do niegodziwości czy zbrodni.

Ogromna konsekwencja, z jaką łotr układa swe zbrodnicze plany, cieszy nas w sposób oczywisty, chociaż jego przygotowania i cel sprawiają przykrość

\footnotetext{
32 „Celowym jednak nazywa się pewien przedmiot lub stan umysłu albo jakąś czynność także wtedy, gdy ich możliwość nie zakłada koniecznie wyobrażenia pewnego celu [a nazywa się tak] z tej racji, że ich możliwość możemy sobie wytłumaczyć i pojąć tylko wtedy, kiedy u jej podstawy założymy przyczynowość kierującą się celami, tj. wolę, która uczyniła je takimi, zgodnie $\mathrm{z}$ wyobrażeniem pewnego określonego prawidła. Celowość może więc być bez celu, o ile przyczyn tej formy nie przypisujemy jakiejś woli...” I. Kant, Krytyka władzy sądzenia, s. 90.
} 
naszemu poczuciu moralnemu. Człowiek taki zdolny jest obudzić w nas najwyższe przejęcie się swymi poczynaniami, tak, że drżymy o powodzenie tych samych planów, których udaremnienia powinniśmy najgoręcej pragnąć, jeśli istotnie miarą wszystkiego czynimy celowość moralną ${ }^{33}$.

To nie widok czyjegoś cierpienia, chęć współodczuwania, czy litości ściąga ludzi do teatru, ale doznanie potęgi ludzkiego ducha, który potrafi zachować swą siłę i autonomię w obliczu wszelkich przeciwności losu ${ }^{34}$. Doznanie współczucia słabnie, gdy mamy do czynienia z męczeństwem przestępcy. Nadal jednak pozostajemy pod wrażeniem duchowej siły Ryszarda III, nie cofającego się przed najgorszymi czynami, oraz potęgi jego rozumu snującego intrygi i zbrodnicze plany. Rozum będzie przy tym odczuwał odrazę, wyobraźnia zachwyt. Rozdźwięk pomiędzy etyką a estetyką widać szczególnie wyraźnie, gdy za przykład weźmiemy czyn, który obie dziedziny ocenią w sposób odmienny. Schiller posługuje się, jako obrazem takiego zdarzenia, opowieścią o Peregrinie Proteuszu, który chciał czymś zasłynąć na Olimpiadzie, ale niestety nie posiadał żadnych odpowiednich po temu umiejętności: nie rzucał oszczepem, ani dyskiem, nie był mocny w zapasach, ani sprawny w jeździe rydwanem. Dokonał więc samospalenia. $\mathrm{Z}$ moralnego punktu widzenia nie sposób tego pochwalić. Ambicja i chęć sławy popychała go bowiem do bardzo mało chwalebnego czynu. Jednak patrząc na całe to zdarzenie z perspektywy estetyki, dostrzegamy, że ów czyn świadczy o potędze woli, która przeciwstawiła się jednemu z najpotężniejszych popędów: zagłuszyła instynkt nakazujący bronić życia w każdych okolicznościach. A to wyobraźni już wystarczy, jako pożywka do imaginacji, dostrzega ona bowiem siłę zdolną pokonać największą nawet potęgę. Wystarczy wyobrazić sobie Peregrina w sytuacji, gdy musiałby wybierać pomiędzy dobrem państwa a nakazem serca. Widać, że zdolny byłby wówczas do zapomnienia o własnym szczęściu, a nawet do pogardzania śmiercią. Może w czasach, gdy żył zabrakło po prostu okazji, by odpowiednio mógł spożytkować swą siłę ducha, a może rozum nie podpowiedział mu właściwej drogi? Dla wyobraźni istotny jest przede wszystkim fakt, że z taką siłą ducha mógłby dokonać czynów wielkich. Istotna jest tu sama możliwość, a nie jej realizacja.

Otóż u podstaw wszelkiej oceny leży wymaganie rozumu, by postępowano moralnie i jest rzeczą bezwarunkowo konieczną, byśmy chcieli tego, co jest

${ }^{33}$ F. Schiller, O powodach, dla których tematy tragiczne dostarczają nam przyjemności, s. 259.

${ }^{34}$ Por. tenże, O sztuce tragicznej, [w:] Goethe i Schiller o dramacie i teatrze, s. 267. 
słuszne. [...] Natomiast przy ocenie estetycznej odnosimy przedmiot do potrzeby wyobraźni, która nie może rozkazywać, lecz tylko pragnąć, aby przypadek okazał się zgodny z jej zainteresowaniem. Wyobraźnia jest zainteresowana $\mathrm{w}$ tym, aby w swym igraniu zachować swobodę wobec praw ${ }^{35}$.

Entuzjazmem estetycznym napawa nas więc samo objawienie się woli zdolnej pokonać potęgę natury, zadrwić $\mathrm{z}$ tego co jest nam przyrodzone, jako istotom biologicznym. Nawet $\mathrm{w}$ tak manierycznym czynie, jak śmierć Peregrina, odnaleźć możemy moc umożliwiającą przeciwstawienie się biologicznemu instynktowi i to wystarczy, by wyobraźnia poczuła się usatysfakcjonowana odnalezioną wolnością istoty ludzkiej od natury. Wyjaśnia to istotę ciekawego fenomenu, kluczowe z perspektywy rozumu i intelektu: że imperatywy Kantowskie w przeżyciu estetycznym czynią gorsze wrażenie niż teatralne samounicestwienie w celu zyskania sławy.

\section{Abstract \\ Why the View of the Suffering Dramatic Characters is Pleasant for Us? Some Considerations about the Influence of Jean-Baptiste Du Bos on Friedrich Schiller}

The main subject of the article is the problem of negative pleasure, or pathos, being a feature of dramatic art. In the XVIII century, in France, Charles Batteux defined art as the human activity whose sole aim is to give pleasure. Seen in this light the plots of dramas, full of intrigues, crimes, and terrifying and even mad characters were in flagrant contradiction with the theory of art understood as pleasure. The leading aestheticians of the century, Jean-Baptiste Du Bos, Gotthold Ephraim Lessing i Friedrich Schiller tried to solve the problem - the last one making use of the aesthetic theory of Immanuel Kant. Their attempts resulted in an interesting conceptions of dramatic art, as using the feeling of sublimity to show the tragedy of the world and of human dignity.

\footnotetext{
${ }^{35}$ tenże, O patetyczności,[ w:] Goethe i Schiller o dramacie i teatrze, s. 301.
} 